\title{
UJI AKTIVITAS ANTIOKSIDAN EKSTRAK METANOL DARI DAUN ALOCASIA MACRORRHIZOS DENGAN METODE DPPH
}

*Syarah Anliza, *Hamtini

\begin{abstract}
Abstrak
Penyakit degenaratif seperti kanker, tekanan darah ting, dan sebagainya semakin banyak dan mudah ditemui dikalangan masyarakat. Pola hidup yang praktis dan instan, khususnya pada pemilihan makanan, memiliki dampak negatif bagi kesehatan. Radikal bebas adalah molekul yang sangat rekatif karena memiliki elektron yang tidak berpasangan dalam orbital luarnya. Kerja radikal bebas dapat dihambat oleh antioksidan yakni zat yang dapat memperlambat dan mencegah terjadinya oksidasi molekul. Adanya senyawa antioksidan mengurangi timbulnya penyakit kronis. Tanaman Alocasia macrorrhizos merupakan tanaman alternatif.

Penelitian ini bertujuan untuk mengetahui aktivitas antioksidan ekstrak metanol dari daun Alocasia macrorrhizos dengan menggunakan metode DPPH. Pelarut yang digunakan adalah metanol. Ekstraksi metanol dari daun Alocasia macrorrhizos dilakukan uji fitokimia untuk mengetahui kandungan pada daun tersebut. Hasil ekstraksi selanjutnya diuji antioksidan dengan menggunakan metode DPPH, yang mana pembanding adalah vitamin $\mathrm{C}$.

Hasil dari penelitian ini didapatkan bahwa ekstrak metanol dari daun Alocasia macrorrhizos terdapat senyawa flavonoid. Hasil uji aktivitas antioksidan didapatkan $\mathrm{IC}_{50}$ sebesar 314,885 ppm.

Kata Kunci : Antioksidan, Ekstrak Metanol, Alocasia macrorrhizos

*Poltekkes Kemenkes Banten
\end{abstract}




\section{Pendahuluan}

Penyakit degenaratif seperti kanker, tekanan darah tinggi, penyakit gula dan lain sebagainya semakin banyak dan mudah ditemui dikalangan masyarakat. Pola hidup yang praktis dan instan, khususnya pada pemilihan makanan, memiliki dampak negatif bagi kesehatan. Makanan cepat saji dengan pemanasan tinggi dan pembakaran merupakan pilihan dominan yang dapat memicu terbentuknya senyawa radikal (Poumorad, 2006). Selain itu, peningkatan polutan hasil pembakaran tidak sempurna kendaraan bermotor dan industri seperti CO (karbon monoksida), oksida-oksida nitrogen dan hidrokarbon merupakan senyawa-senyawa yang rentan teroksidasi menjadi senyawa radikal . Begitu juga global warming atau peningkatan suhu bumi akibat penipisan lapisan ozon yang berarti radiasi sinar ultraviolet semakin intensif menyerang manusia dan menginduksi terbentuknya suatu radikal (Jain dkk, 2004).

Fakta-fakta telah menunnjukkan bahwa kecenderungan keberadaan senyawa-senyawa radikal bebas dalam tubuh semakin meluas. Radikal bebas adalah molekul yang sangat rekatif karena memiliki elektron yang tidak berpasangan dalam orbital luarnya. Radikal bebas dapat bereaksi dengan molekul yang merupakan komponen sel tubuh dengan cara mengikat elektron molekul. Radikal bebas tersebut dapat mengoksidasi asam nukleat, protein, lemak bahkan DNA sel dan menginisiasi timbulnya penyakit degenartif (Reynertson, 2007).

Kerja radikal bebas dapat dihambat oleh antioksidan yakni zat yang dapat memperlambat dan mencegah terjadinya oksidasi molekul. Adanya senyawa antioksidan mengurangi timbulnya penyakit kronis yang disebabkan karena kerja radikal bebas dalam tubuh seperti kanker, disfungsi otak dan inflamasi yang dapat menyebabkan kematian. Tubuh dapat menghasilkan antioksidan dari metabolisme sel tubuh namun dengan meningkatnya jumlah radikal bebas, tubuh perlu didukung oleh asupan antioksidan. Hal tersebut melatarbelakangi dilakukannya penelitian sebagai upaya menemukan sumber baru antioksidan yang dapat mengimbangi peningkatan radikal bebas di dalam tubuh (Ginting dkk, 2009). Salah satu upaya tersebut adalah mengeksplor dan menemukan senyawasenyawa antioksidan seperti beta karoten, astasantin, alkaloid, dan fenol pada 
tumbuhan. Menurut Depkes, (2007) baru sekitar 9.600 tanaman yang diteliti khasiatnya sebagai obat dan kurang lebih 300 tanaman telah digunakan sebagai bahan obat tradisional oleh industry obat tradisional.

Tanaman Araceae merupakan tanaman yang diduga memiliki kandungan yang diantaranya adalah flavonoid dan saponin (Biren et al, 2007). Salah satu golongan tanaman Araceae adalah tanaman Alocasiamacrorrhizos yang biasa dikenal dengan tanaman sente. Tanaman ini tumbuh liar di daerah tropis. Tanaman ini memiliki daun berbentuk perisai, warna daun yang sangat bervariasi tergantung varietasnya, dan tumbuh hingga 1,2 - 1,8 $\mathrm{m}$ diketinggian dibawah kondisi yang menguntungkan. Tanaman ini mengandung senyawa flavonoid, glikosida, asam askorbat, asam galat, asam malat,asam oksalat, asam suksinat dan $\beta$-lektin (Rahman et al, 2012). Menurut (Srivastava el al, 2012) bahawa pada tanaman Alocasia macrorrhizosdapat berguna sebagai antifungal, analgesik, antitumor dan antioksidan. Berdasarkan hasilnya pada ekstrak dietil eter dari akar, daun dan rhizom menunjukkan aktivitas antioksidan dengan $\quad \mathrm{IC}_{50}$ sebesar $34.51 \pm 2.72$, 103.39 \pm 7.12 , dan $48.01 \pm 6.68 \mu \mathrm{g} / \mathrm{mL}$. Oleh karena itu pada penelitian ini dilakukan untuk mengetahui aktivitas antioksidan ekstrak metanol dari daun Alocasia macrorrhizos.

\section{Metode Penelitian}

Jenis penelitian yang akan dilakukan adalah eksperimen, dengan melakukan uji aktivitas antioksidan pada ekstrak metanol dari daun Alocasia macrorrhizos. Populasi berasal dari pohon Alocasia macrorrhizos yang ada di daerah Pondok Labu, Jakarta Selatan. Sampel yang digunakan adalah daun Alocasia macrorrhizos yang segar dan berwarna hijau. Data yang digunakan dalam penelitian ini yaitu data primer dengan uji laboratorium isolasi dan uji antioksidan ekstrak metanol dari daun Alocasia macrorrhizos

\section{Hasil}

Berdasarkan hasil dari simplisia daun Alocasia macrorrhizos yang telah di ekstraksi dengan metanol, maka dilakukan uji fitokimia. Hasil fitokimia menunjukkan adanya positif dua (++) pada flavonoid.

Pengukuran aktivitas antioksidan pada ekstrak metanol daun Alocasia macrorrhizos dilakukan dengan menggunakan metode DPPH. Hasil 
aktivitas antioksidan dapat dilihat pada

Tabel 1. Hasil uji aktivitas antioksidan

\begin{tabular}{|l|c|}
\hline Sampel & IC50 (ppm) \\
\hline Ekstrak metanol & 314,885 \\
\hline $\begin{array}{l}\text { Vitamin C } \\
\text { (Pembanding) }\end{array}$ & 3,4295 \\
\hline
\end{tabular}

\section{Pembahasan}

Tanaman yang digunakan pada penelitian ini adalah daun Alocasia macrorrhizos yang diperoleh dari Pondok Labu, Jakarta Selatan. Daun Alocasia macrorrhizos dibersihkan, dikeringkan, dan dihaluskan menggunakan grinder untuk memperkecil ukuran simplisia, dan selanjutnya diekstraksi. Tahapan ekstraksi merupakan tahapan penting untuk mengidentifikasi bioaktif yang terdapat dalam sampel daun Alocasia macrorrhizos. Ekstraksi dilakukan menggunakan metanol dengan metode maserasi. Pelarut ini dipilih karena kemampuannya dalam menarik komponen-komponen yang ada pada sampel sangat kuat sehingga dapat menarik seluruh senyawa metabolit sekunder dari mulai senyawa polar hingga non polar (Suwendiyanti, 2014).

Hasil uji fitokimia yang dilakukan pada pelarut yang berbeda akan
Tabel 1.

menunjukkan hasil yang berbeda dalam kekuatan sinyal yang diidentifikasi, yaitu tingkat kepekatan yang berbeda pada setiap pelarut (Egwaikhide \& Gimba 2007). Hasil uji fitokimia pada ekstrak metanol daun Alocasia macrorrhizos menunjukkan bahwa positif terhadap flavonoid. Flavonoid ditandai dengan adanya warna merah, kuning, dan jingga pada lapisan amil alkohol, Flavonoid merupakan golongan terbesar dari fenol dan terdapat dalam bentuk aglikon maupun glikosida dalam tanaman. Penelitian yang dilakukan oleh Srivastava et al.(2012)terhadap daun Alocasia macrorrhizos memperlihatkan adanya kandungan flavonoid, protein, glukosida, dan turunan steroid (ergosterol dan kolesterol). Kelompok senyawa yang bertanggung jawab dalam aktivitas antioksidan daun Alocasia macrorrhizos diduga berasal dari senyawa flavonoid.

Uji aktivitas antioksidan dilakukan untuk mengetahui kapasitas senyawa aktif dalam ekstrak untuk menangkap radikal bebas. Aktivitas antioksidan ekstrak metanol daun Alocasia macrorrizhos diukur menggunakan metode DPPH $(1,1$ diphenyl-2-picrylhydrazil).

DPPH merupakan senyawa radikal bebas yang stabil dan tidak membentuk dimer akibat 
delokalisasi dari elektron bebas pada seluruh molekul. Uji aktivitas antioksidan dengan menggunakan metode ini didasarkan pada hilangnya warna ungu akibat tereduksinya DPPH oleh senyawa antioksidan dalam sampel, sehingga menghasilkan senyawa DPP Hidrazin (DPPHH) berwarna kuning. Metode ini tidak memerlukan substrat sehingga lebih sederhana dengan waktu analisis yang lebih cepat (Molyneux 2004). Metode DPPH telah banyak digunakan dalam analisis antioksidan seperti pada penelitian Anwariyah (2011) yang mengkaji aktivitas antioksidan lamun Cymodocea rotundata dengan metode DPPH, selain itu Irianti et al. (2011) menguji aktivitas antioksidan DPPH oleh ekstrak etanolik batang brotowali dan fraksi-fraksinya.

Pengujian aktivitas antioksidan pada penelitian ini akan dibandingkan dengan aktivitas antioksidan yang dihasilkan oleh asam askorbat. Asam askorbat (vitamin C) dikenal sebagai antioksidan yang kuat karena dapat mendonorkan atom hidrogen dan membentuk radikal bebas askorbil yang relatif stabil seperti anion askorbat yang dapat menerima atom hidrogen lain dan membentuk asam dehidroaskorbat. (Hart et al. 2003).
Aktivitas antioksidan hasil penelitian dinyatakan dalam IC50, yaitu konsentrasi zat antioksidan yang menghasilkan persen penghambatan DPPH sebesar $50 \%$. Nilai IC50 diperoleh melalui persamaan linier antara persen inhibisi dengan konsentrasi sampel. Semakin rendah nilai IC50 maka daya hambat ekstrak terhadap radikal bebas semakin tinggi. Menurut Jun et.al 2003, aktivitas antioksidan digolongkan sangat aktif jika nilai IC50 kurang dari 50 ppm, digolongkan aktif bila nilai IC50 50-100 ppm, digolongkan sedang bila nilai IC50 101- 250 ppm, dan digolongkan lemah bila nilai IC50 250-500 ppm, serta digolongkan tidak aktif bila nilai IC50 lebih besar dari 500 ppm.

$$
\text { Berdasarkan nilai IC50 yang }
$$
diperoleh, ekstrak metanol daun Alocasia macrorrhizosmemiliki aktivitas antioksidan dengan nilai IC50 sebesar 314,885 ppm dan tergolong antioksidan lemah. Aktivitas antioksidan yang lemah kemungkinan disebabkan oleh struktur kimianya yang tidak memiliki gugus hidroksi fenolik yang banyak dan tidak memiliki ikatan rangkap pada C2-C3 pada struktur flavonoid, yang dapat meningkatkan kapasitas stabilisasi radikal flavonoid yang terbentuk. Oleh karena itu 
aktivitas antioksidan kemungkinan hanya disumbangkan oleh gugus hidroksi fenolik pada cincin lainnya. Menurut Widyawati $e t$ al. (2010), perbedaan aktivitas antioksidan dapat disebabkan oleh beberapa faktor, seperti perbedaan kemampuan dalam mentransfer atom hidrogen ke radikal bebas, struktur kimia senyawa antioksidan, dan $\mathrm{pH}$ campuran reaksi.

\section{Simpulan}

Analisis kualitatif yang dilakukan pada ekstrak metanol daun Alocasia macrorrizhos menunjukkan bahwa mengandung senyawa flavonoid. Analisis kuantitatif pada aktivitas antioksidan menunjukkan bahwa nilai $\mathrm{IC}_{50}$ yang diperoleh 314,885 ppm. Berdasarkan hasil penelitian, maka dapat disimpulkan bahwa ekstrak metanol daun Alocasia macrorrizhos memilki antioksidan tetapi bersifat lemah.

\section{Daftar Pustaka}

Biren, N.S., Nayak, B.S, Bhatt, S.P, Jalalpure., S.S., Seth., A.K. 2007. The Anti-imflamatory activity of The Leaves of Colocasia esculenta. SPJ, Vol. 15. 3-4

Departemen Kesehatan Republik Indonesia.2007. Kebijakan Obat Tradisional Nasional. Jakarta (ID): Departemen Kesehatan Republik Indonesia. Egwaikhide PA, Gimba CE. 2007. Analysis of the phytochemical content and anti- microbial activity of plectranthus glandulosis whole plant. MiddleEastJournal of Scientific Research 2(34):135-138.

Ginting, M., A.M. Satria \& R. Khalil. 2007. Perairan Nusantara. Universitas Diponegoro.

Hart, Harold. 2003. Kimia Organik Suatu Kulaih Singkat. Erlangga: Jakarta

Jain, K. 2004. Effect of UV-B radiation on antioxidant enzymes and its modulation by benzoquinone and $\alpha$ tocopherol in cucumber cotyledons, Current Science. 87 (2): 2-15.

Molyneux, P. 2004. The use of the stable free radical diphenylpicrylhydrazyl (DPPH) for estimating antioxidant activity. Songklanakarin J.Sci. Technol.

Poumorad, F., Hosseinimehr \& Shahabimajd. 2006. Antioxidant activity phenol and flavonoid contents of some selected Iranian medicinal plants, African Journal of Biotechnology 1 : $1142 \quad-$ 1145.Rahman, Masudur., Hossain, Aslam., Alam, Saiful Siddique, Parvej, Kaishar BIPLAB, Uddin, Helal. 2012. Antihyperglycemic, antioxidant, and, cytotoxic activities of Alocasia macrorrhizos (L) rhizome extract. Turk J Biol. 36: 574 - 579

Reynertson, K.A. 2007. Phytochemical analysis of bioactive constituens from edible myrtaceae fruit. University of New York, New York.

Srivastava, Vivek, Mubeen, Sheikh, Chand, Bhupesh Semwal, Misra, Vimlesh. 2012. Biological Activities Of Alocasia Macrorrhizos : a Review. Journal of Science. ISSN- 2277 1883.

Suwendiyanti, R. 2014. Efektivitas Ekstrak Akar, Batang, Kulit Batang, Daun, dan Fraksi Avicennia marina Sebagai Antioksidan, Skripsi, Universitas Padjadjaran. 